\title{
The Strategic Role of Private Labels on Retail Competition
}

\author{
M. Tolga Akçura* \\ Özyeğin University
}

\author{
Ram Bezawada** \\ SUNY
}

\author{
Ajay Kalra*** \\ Rice University
}

\begin{abstract}
We investigate the strategic role of private labels in limiting retail competition. Private labels are unique differentiators for retailers. By launching and credibly committing to a strong private label program, a strong retailer can limit the market potential for competing retailers. Consequently, weaker retailers may not be able to meet threshold profits and exit the market. We derive the private label shares needed to induce exit. A model implication is that the private label share required to induce exit increases with increasing national brand margins. We also conduct an empirical analysis and find evidence supporting the propositions. Combining Dominick's store level data with Zip Code Business Patterns data, we find that at the zip code level, the private label share affects the number of stores competing in the market.
\end{abstract}

Keywords: limited competition, private labels, competitive retail strategy.

\section{Market Markalarının Perakende Rekabeti Üzerindeki Stratejik Rolü}

\section{Özet}

Bu makalede perakendecilerin taşıdıkları özel etiketli markaların piyasadaki rekabeti nasıl sınırlayabileceğini inceliyoruz. Özel etiketler perakendeciler için benzersiz ayırd edici özellikler sunarlar. Kendi markalarını ve özel etiketlerini piyasaya sürüp bu tür markalar üzerine inandırıcı pazar payı elde etme taahhütünü vererek, kuvvetli bir perakendeci rakip diğer perakendicilerin pazar potansiyelini sınırlayabilir. Bu sayede, zayıf perakendeciler, pazarda ayakta kalmak için gerekli olan kritik ciroyu elde edemiyeceklerinden pazardan ayrılırlar. Zayıf rakiplerin piyasadan ayrılmasını sağlamak için gerekli olan özel etiketlerin elde etmesi gereken pazar payını hesapladık. Modelin bir sonucu olarak, her perakendecide bulunan ulusal markaların kar oranlarının artmasının rekabeti sınırlamak için gerekli olan özel etiket pazar payının artmasına neden olduğunu gördük. Empirik çalışmamız analitik olarak geliştirdiğimiz önermeleri destekliyor. US' de bulunan Dominick’s supermarket datasıyla, posta kodunda bulunan işletmeleri anlatan Zip

\footnotetext{
M. Tolga Akçura is an Associate Professor in the Department of Management at Özyeğin University, Altunizade, Istanbul, Turkey. E-mail: tolga.akcura@ozyegin.edu.tr

** Ram Bezawada is an Assistant Professor in the School of Management at SUNY, Buffalo, NY, 14260, U.S.A. E-mail: bezawada@buffalo.edu

**** Ajay Kalra is a Professor at Jesse H. Jones School of Management, Rice University, Houston, TX, 77005, U.S.A. E-mail: ajay.kalra@rice.edu
} 
Code Business Patterns datasını birleştirerek, posta kodu seviyesinde, perakendecinin özel etiketinin elde ettiği pazar payının rakip mağaza sayısını etkilediğini bulduk.

Anahtar kelimeler: sınırlandırılmış rekabet, özel etiketler, rekabetçi perakende stratejisi.

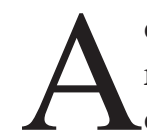

ccording to the Private Label Manufacturers Association (PLMA) and industry reports, supermarkets increasingly use private labels to reassert themselves competitively in their geographic markets (Store Brands Decisions, 2010; PricewaterhouseCoopers, 2009; Chain Store Age, July, 2005; PROMO, January, 2005; Supermarket News, 2000). There is anecdotal evidence that private labels drive retailer success (McKinsey Quarterly, 2011; The Hub Magazine, 2010). According to the Food Marketing Institute, "As retail competition intensifies across the nation, private label store brands have become a key driver in total store sales" (FMI: 2003) and "Expansion of store brands is a key way retailers are creating marketable differentiation, ranking second only to product freshness" (FMI: 2010). A benchmark report concludes that "Retail winners, those whom we gauge to outperform their peers in year-over-year comparable store sales, carry a significantly higher percentage of private label merchandise than their underperforming brethren" (Rosenblum, 2007).

Supermarkets frequently invest in programs that enable them to increase their overall private label market shares and often announce their aggressive private label targets (Progressive Grocer, September, 2002). In 2006, the average share of private labels in the U.S. market was nearly $21 \%$ in terms of volume sales but several retailers were setting goals of 25\%, 30\% or more for their brands for 2007 (PLMA e-scanner, 2007). For example, SuperValu announced the objective of increasing its private labels share from 16.5\% to 30\% (Private Label Buyer, 2007). Also, Costco announced that its goal was to increase private label share from $16-17 \%$ to $20 \% .^{[1]}$ The objective to increase private label shares by some retailers is also echoed in non-U.S. markets. The Australian chain Coles announced its sales goal of increasing its private label share to $30-40 \%$ in $2007^{[2]}$ and the German drugstore retailer Ihr Platz also plans to triple the sales of its private label products with the goal of raising its market share to $18 \% .^{[3]}$

The emphasis on private labels is not surprising as they help retailers in a number of ways. They may be used against national brand manufacturers to elicit concessions (Scott-Morton and Zettelmeyer, 2004; Narasimhan and Wilcox, 1998). Ailawadi and Harlam (2004) empirically show a positive relationship between national brand margins and increasing private label shares. Private labels can also be used for price discrimination (Wolinsky, 1987) and/or help retailers to increase their channel profits when competing against national brand manufacturers (Raju, Sethuraman and Dhar, 1995). Retailers also benefit from private labels through increased retailer loyalty and differentiation (Corstjens and Lal, 2000). The empirical evidence for this benefit is somewhat mixed.

\footnotetext{
${ }^{[1]} \mathrm{http}: / /$ plma.com/scanner/summer2006.html

${ }^{[2]}$ http://www.accessmylibrary.com/coms2/summary_0286-13885545_ITM

${ }^{[3]}$ http://www.plmainternational.com/EscannerInt/March2007En.html
} 
A few studies confirm this relationship (e.g., Corstjens and Lal, 2000; Ailawadi et al., 2001) while other studies do not find a strong association between store loyalty and degree of private label purchases (Ailawadi and Harlam, 2004).

In this article, we argue that another benefit of high private labels sales is that they can also be used to enhance competitiveness in a market and thereby facilitate exit or deter entry of competing stores. Increasingly, managers and retail analysts in Wall Street acknowledge the importance of private labels in obtaining a higher market share due to retail level competitive pressures. For example, the vice president of Macy's stated that "private labels had been vital to Macy's success in differentiating the store from its competition" and comments that "If private labels didn't exist, there would be no reason to shop at Macy's rather than Nordstrom's." "[4] According to a Wall Street analyst, "The increase in private labels will accelerate the fall out of smaller companies." ${ }^{[5]}$ Furthermore, retailers exert control over both the private labels as well as national brands (Hoch, Montgomery and Park, 2004). All these factors indicate that the nature of the competitive effects when private label sales increase needs further examination.

By announcing their private label targets, retailers also communicate their intention to increase the competitiveness of the market. Private labels are powerful strategic tools as compared to other elements of the marketing mix that retailers can alternatively employ. Unlike other strategic variables such as lowering prices, increasing advertising or service levels, which can be more easily replicated by competitors with similar resources, private labels are unique to a retailer and therefore provide a source of longterm competitive advantage which may help in limiting competition.

Additionally, unlike other strategic variables, private labels are also credible devices for limiting competition as they sometimes involve considerable upfront investments and may indicate continuing long-term commitment. For example, the supermarket chain Publix owns its own 5 manufacturing facilities to make private labels while Kroger owns 42 plants (Publix and Kroger official websites). Other launch costs are associated with the production and marketing of private labels. For example, Safeway spent $\$ 100$ million for launching its products and uses Disney/Pixar characters for its private labels (Private Label Magazine, 2005). An industry report states that basic costs in launching private label nutritional supplements exceed $\$ 12 \mathrm{~m}$. Given the low margins, such investments require a long time to break even ${ }^{[6]}$ The continuing commitment can also be exhibited contractually. For example, Kmart has guaranteed a payment of $\$ 365.2$ million starting from 2002 through 2010 to Martha Stewart Living Omnimedia Inc (Company 10Q reports filed with SEC).

We first develop a simple analytical model and analyze the role of private labels on retailer strategies. We demonstrate that a retailer with a relative competitive advantage in its private label product can enable the exit of a competitor with a weaker private label product. By launching and credibly committing to a strong private label program,

\footnotetext{
${ }^{[4]}$ San Francisco Chronicle, May 5, 2006.

${ }^{[5]}$ Apparel, Analysts Perspectives, July 2003. See also McLauglin (2004).

${ }^{[6]}$ http://www.naturalproductsinsider.com/articles/473/473_381privlabfoc1.html
} 
a retailer can increase the competitiveness of its market. Consequently, when the retailer with the private label product advantage increases its private label sales, the market profitability decreases along with a decline in the profitability of the competing retailer. Eventually, the competitor cannot meet threshold profits to survive and exits the market. One implication of our model is that the private label sales required for limiting competition increase with increasing national brand margins. Using data from a grocery chain, we empirically test and find support for the main insights of the model. This is the first paper in the literature that shows the anti-competitive role of private labels in limiting retail-level competition.

The rest of the paper is organized as follows: The analytical model is discussed in the next section. Following the analysis of the analytical model, we provide an empirical analysis and show the validity of the analytical model. The last section is a summary of our conclusions.

\section{Model}

We develop a model to show that emphasizing a private label increases competitiveness thereby making a market less profitable. The reduced attractiveness of the market could alter market conditions thereby making it more likely for a competitor to exit. In the model, there are two competing asymmetric retailers facing a downward sloping demand curve. One retailer is relatively strong and acts as the Stackelberg leader in the market. Retailers set their quantity decisions to maximize their profits.

Consider a geographical market where there are two retailers. Alternatively, the market can consist of several retailers where the two retailers of interest are the key representative and the close competitor. The intuition of the model still applies. The focal retailer $s$ and competing retailer $w$ sell the same national brands and charge identical prices. Any price decrease (or increase) can be matched by the competitor. All retailers in the market require a threshold level of profit to stay in business which is given by $T$.

With similar national brands, all retailers equally share the overall national brand demand. Each retailer's national brand sales is represented by $q_{n b}$ where $q_{n b}$ represents the composite of all national brands. Given a national brand price $p$, the retailers face an overall national brand demand of $1-c-m$ where $m$ is the retailer margin (equals to $p-c$ ), $c$ is the national brand unit cost. Then, the retailer profit equals $m q_{n b}$. Retailers stay in any market provided the profit is greater than a threshold $T$. Thus, both retailers obtain the same margin $(m)$ where $m q_{n b}=T$.

For the sake of simplicity, we consider that the focal retailer $s$ has a first mover advantage over the $w$ retailer for its private label. This advantage helps retailer $s$ create a stronger preference for its private label. Alternatively, it can be conceptualized that the $s$ retailer has more expertise, better managers or better access to financial markets than the other retailer. Essentially, all that is required is that the strong $(s)$ retailer has the ability to create a competitive advantage for its private label over the weak $(w)$ type retailer. The competing retailer $w$ reacts by also introducing a private label but cannot match the consumer preference created by the focal retailer. 
The private label unit cost is denoted by $c_{p l}$ and the fixed cost incurred in the launch of the private label is $F$. The demand for strong $s$ and weak $w$ private labels are given by:

$$
\begin{aligned}
& q_{p l}^{s}=\dot{A}-p_{p l}^{s}+\dot{a}_{1} p_{p l}^{w}+\dot{a}_{2} p_{n b}, \\
& q_{p l}^{w}=\dot{B}-p_{p l}^{w}+\dot{b}_{1} p_{p l}^{s}+\dot{b}_{2} p_{n b},
\end{aligned}
$$

where $\dot{A}, \dot{B}$ capture the base line demands, $\dot{a}_{1}, \dot{b}_{1}$ and $\dot{a}_{2}, \dot{b}_{2}$ represent cross price elasticities. The relative consumer demand is influenced by the prices and the relative product quality (captured by $\dot{a}_{1}, \dot{a}_{2}, \dot{b}_{1}$ and $\dot{b}_{2}$ ). For ease of exposition, we normalize own price elasticities to 1 . Following the generalized findings in the literature, brands' own price elasticities are higher than the cross elasticities (e.g., Sethuraman, Srinivasan and Doyle, 1999; Bucklin and Srinivasan, 1991). Also, as empirical evidence indicates, there are asymmetric effects between stronger and weaker brands (e.g., Blattberg and Wisniewski, 1989). These asymmetric effects apply to competition between the national brand and private labels as well as between the strong and weak private labels. For example, with increasing quality difference between the strong private label and the weak private label, $\dot{b}_{1}-\dot{a}_{1}$ increases; a low $\dot{a}_{1}$ and $\dot{a}_{2}$ capture a strong, high quality private label.

The focal retailer requires a credible device to increase the competitiveness of the market to induce the competitors' exit. Among the options available are decreasing national brand prices, increasing advertising levels or increasing service levels. A price decrease of national brands is not credible (Tirole, 1988; Milgrom and Roberts, 1982; Friedman, 1979) as prices can be changed immediately. Other potential devices such as improving service levels or increasing advertising also lack credibility using the same argument. One credible route is to enter into an advanced commitment when a firm makes an irrevocable investment decision where post exit, the competitor would believe that the firm's investment would be the same as the pre-exit investment (e.g. Dixit, 1980). For retailers, one such credible decision can be to announce their commitment to their private label program. As discussed in the motivational examples, it is possible for firms to credibly commit to their private label programs. The firm commits to the costs upfront. Given a quantity of $q_{p l}$ and a unit cost of $c_{p l}$, the firm incurs the $\operatorname{cost} q_{p l} c_{p l}$ which covers future production. Such investments in private labels directly reveal an undertaking to achieve high sales levels in private labels. Upon seeing the focal retailer's commitment $q_{p l}$, the competing retailer sets its strategy and decides whether to exit or not.

We now adopt the mathematically equivalent inverse demand functions to discuss the model. By solving equations (1) and (2), the prices of the private labels are given by:

$$
\begin{aligned}
& p_{p l}^{s}=\frac{\dot{A}+\dot{a}_{1} \dot{B}-q_{p l}^{s}-\dot{a}_{1} q_{p l}^{w}+\left(\dot{a}_{2}+\dot{a}_{1} \dot{b}_{2}\right) p_{n b}}{1-\dot{a}_{1} \dot{b}_{1}}, \\
& p_{p l}^{w}=\frac{\dot{B}+\dot{b}_{1} \dot{A}-q_{p l}^{w}-\dot{b}_{1} q_{p l}^{s}+\left(\dot{b}_{1} \dot{a}_{2}+\dot{b}_{2}\right) p_{n b}}{1-\dot{a}_{1} \dot{b}_{1}} .
\end{aligned}
$$


For each unit of private label quantity that the retailers sell, the overall national brand demand decreases. Post private label introduction by the two retailers, the overall national brand demand $\left(2 q_{n b}\right)$ becomes $1-c-m-q_{p l}^{s}-q_{p l}^{w}$. We can write equations (3) and (4) in terms of national brand demand. In general, we can write the inverse demand functions as: ${ }^{[7]}$

$$
\begin{aligned}
& p_{p l}^{s}=A^{\prime}-a^{\prime} q_{p l}^{s}-a_{1}^{\prime} q_{p l}^{w}-a_{2}^{\prime} q_{n b}, \\
& p_{p l}^{w}=B^{\prime}-b^{\prime} q_{p l}^{w}-b_{1}^{\prime} q_{p l}^{s}-b_{2}^{\prime} q_{n b} .
\end{aligned}
$$

Now, we determine the profit function for both retailers. The profits of the strong and weak retailers are:

$$
\begin{aligned}
& \Pi^{s}=m q_{n b}+q_{p l}^{s}\left(A^{\prime}-a^{\prime} q_{p l}^{s}-a_{1}^{\prime} q_{p l}^{w}-a_{2}^{\prime} q_{n b}-c_{p l}^{s}\right)-F^{s}, \\
& \Pi^{w}=m q_{n b}+q_{p l}^{w}\left(B^{\prime}-b^{\prime} q_{p l}^{w}-b_{1}^{\prime} q_{p l}^{s}-b_{2}^{\prime} q_{n b}-c_{p l}^{w}\right)-F^{w} .
\end{aligned}
$$

The retailers make their decisions that maximize their profits. The strong retailer moves first and sets its private label decision by considering the best response function of the weak retailer.

As discussed before, the strong retailer makes a commitment of $q_{p l}^{s}$ units and incurs the $\operatorname{cost} q_{p l}^{s} c_{p l}^{s}$. The commitment ensures that $q_{p l}^{s}$ in equation (7) is fixed and will not decrease. The weak retailer sees this commitment and decides on its strategy. Given the strong retailer's quantity commitment of $q_{p l}^{s}$ units, the optimal best response for the weak retailer requires that it sells $q_{p l}^{w^{*}}=\frac{B-0.5 b_{1} q_{p l}^{s}}{b}$, where $B=B^{\prime}-0.5 m\left(1-b_{2}^{\prime}\right)-0.5 b_{2}^{\prime}(1-c)-c_{p l}^{w}$, $b_{1}=2 b_{1}^{\prime}-b_{2}^{\prime}$, and $b=2 b^{\prime}-b_{2}^{\prime}$. The optimal quantity that the strong retailer needs to commit as part of its duopoly first best strategy is: $q_{p l}^{s^{*}}=\frac{A-a_{1} B / 2 b}{a-a_{1} b_{1} / 2 b}$, where $A=A^{\prime}-0.5 m\left(\left(1-0.5 b_{1} / b\right)-a_{2}^{\prime}\right)-0.5 a_{2}^{\prime}(1-c)-c_{p l}^{s} \quad, a_{1}=2 a_{1}^{\prime}-a_{2}^{\prime}, a=2 a^{\prime}-a_{2}^{\prime} . A$ and $B$ capture the relative attractiveness of private labels compared to the national brands. $a_{1}$ and $b_{1}$ represent the price sensitivities.

The optimal private label sales depend on their relative qualities. We can see that $q_{p l}^{s^{*}}>q_{p l}^{w^{*}}$ when $A \geq B$. Note that $q_{p l}^{s}>q_{p l}^{w^{*}}=\frac{B-0.5 b_{1} q_{p l}^{s}}{b}$ if $q_{p l}^{s}>\frac{B}{b+0.5 b_{1}}$. But, $q_{p l}^{s^{*}}=\frac{A-a_{1} B / 2 b}{a-a_{1} b_{1} / 2 b}>\frac{B}{b+0.5 b_{1}}$ (see Appendix). Given a fixed $q_{p l}^{s}$, with increasing private label price sensitivity of the $w$ retailer ( $b_{1}$ increases), the optimal quantity sold by the $w$

$$
\text { [7] } \begin{aligned}
p_{p l}^{s} & =\frac{\dot{A}+\dot{a}_{1}\left(\dot{B}+\dot{b}_{2}\right)+\dot{a}_{2}-\left(\dot{a}_{2}+\dot{a}_{1} \dot{b}_{2}+1\right) q_{p l}^{s}-\left(\dot{a}_{1}+\dot{a}_{2}+\dot{a}_{1} \dot{b}_{2}\right) q_{p l}^{w}-2\left(\dot{a}_{2}+\dot{a}_{1} \dot{b}_{2}\right) q_{n b}}{1-\dot{a}_{1} \dot{b}_{1}}, \\
p_{p l}^{w} & =\frac{\dot{B}+\dot{b}_{1}\left(\dot{A}+\dot{a}_{2}\right)+\dot{b}_{2}-\left(\dot{b}_{2}+\dot{b}_{1} \dot{a}_{2}+1\right) q_{p l}^{w}-\left(\dot{b}_{1}+\dot{b}_{2}+\dot{b}_{1} \dot{a}_{2}\right) q_{p l}^{s}-2\left(\dot{b}_{2}+\dot{b}_{1} \dot{a}_{2}\right) q_{n b}}{1-\dot{a}_{1} \dot{b}_{1}} .
\end{aligned}
$$


retailer $\left(q_{p l}^{w^{*}}\right)$ decreases. In addition, as $b_{1}$ increases, retailer $s$ increases its private label sales $\left(q_{p l}^{s^{*}}\right)$. As $b_{1}-a_{1}$ increases, retailer $s$ private label sales increase. Therefore, retailer $s$ benefits from a high quality private label. The private label decision for both retailers is of course contingent on the cross price elasticities. When cross price elasticities between the private labels become more asymmetric, the weak retailer finds it more profitable to decrease private label sales and emphasize the national brand.

We see that with increasing private label sales of retailer $s$, retailer $w$ 's best response $\left(\frac{B-0.5 b_{1} q_{p l}^{s}}{b}\right)$ calls for a decreasing private label sales $\left(b_{1}=2 b_{1}^{\prime}-b_{2}^{\prime}>0\right)$. The results indicate that retailer $w$ would be better off to sell lower private label units (and increase private label prices) as $q_{p l}^{s}$ increases.

Retailer $w$ can react to the private label sales increase of retailer $s$ by increasing its own private label sales. The trade off the $w$ retailer faces is that, on the one hand, it increases the profit due to the higher private label sales and, on the other hand, it cannibalizes sales from the national brand sales and hurts the national brand profits. Given a downward sloping demand curve, the retailer initially benefits from increasing private label unit sales. However, as private label sales increase, the marginal benefit of selling private labels decreases and the marginal cost due to the national brand cannibalization increases. When the marginal cost of cannibalization outweighs the marginal benefit, the $w$ retailer does not increase its private label sales further. As retailer $s$ commits to higher private label sales, the total market for national brands decreases. Therefore, the benefit of additional private label sales for retailer $w$ decreases. Consequently, the weak retailer finds it beneficial to decrease its private label sales. This results in overall lower sales for retailer $w$ compared to retailer $s$.

So far, we have considered the case where both retailers can meet threshold profits after introducing private labels. Essentially, the strong retailer's objective is to meet threshold profits $T$ while ensuring that the weak retailer does not meet the threshold. When the strong retailer commits to private label sales above a certain level, $q_{p l}^{s} \geq 2 B / b_{1}$, the optimal weak private label sales become zero. This is the point where the weak private label retailer cannot benefit from increasing private labels and must rely on national brands. Since the weak retailer loses some of its national brand sales to the private label of retailer $s$, retailer $w$ needs to charge higher national brand prices in order to sustain a threshold level of profit. But, retailer $s$ has no incentive to increase its own national brand prices since it can obtain the threshold level of profit. This results in a lower profit for retailer $w$ and if the profits become lower than the threshold $T$, the weak retailer exits the market.

\section{Proposition 1}

If the strong retailer credibly communicates a sufficiently high private label target sales, the weak retailer exits the market.

To facilitate exit, the strong retailer has to ensure that the weak retailer's profit is less than the threshold. The threshold profit is comprised of the national brand margins and the private label margins. With increasing commitment by the strong retailer to 
private label sales, the profits from the national brand shrink for the weak retailer. The ability to continue in the market then is based on the profits accrued from the national brand. If the national brands margins are high, the ability to meet threshold profits is greater. Therefore, the strong retailer is forced to commit to even larger private label sales to obtain exit.

\section{Proposition 2}

As national brand margins increase, the private label sales necessary to limit competition increase.

\section{Empirical Analysis}

A key insight of the paper is that focus on private label shares will lower competition by reducing the number of competing stores. The primary aim of the empirical analysis is to test this proposition. We also test the model result which implies that high national brand margins are associated with increased private label shares that, in turn, will reduce competition.

We use a store level dataset provided by Dominick's Finer Foods (DFF), a major regional supermarket chain in the Midwest that accounts for approximately $27 \%$ of the market sales. Across the market, the Dominick's private label program has been considered to be a strong one with high market shares (Dhar and Hoch 1997, Progressive Grocer, 1997). There are seventy-five stores that offer private labels at the beginning of our observation period. We compile yearly information on prices, and private label dollar shares for 22 categories in 75 stores for a period of five years (1993-97). The overall number of stores for Dominick's does not show a trend and is stable during the period. The DFF dataset contains demographic information for each store. We use the number of households residing in a given zip code (US Census Bureau) as a proxy for market size. To obtain the number of competitors per store, we use the Zip Code Business Patterns (ZBP) data published by the U.S. Department of Commerce. This dataset contains the total number of grocery stores (SIC code 5410) tabulated according to the number of employees per five-digit zip code starting from year 1994 (this gives us 68 unique zip codes). In ZBP dataset, we consider only major stores that have at least 10 employees, and exclude convenience and mom-and-pop type smaller stores. We assume that each store is competing with DFF in all the categories (for a description of the categories, see Table 1). Although the original data set has 29 categories, some categories do not have any private label sales (e.g., front-end candies). In addition, some other categories are excluded because a large part of purchases in the category may occur at other store formats (e.g., beers, cigarettes). On average, private labels offer $35 \%$ of the UPCs offered by national brands. The private label shares range between $1 \%$ in frozen entrees to $28 \%$ in frozen juice, with an overall mean of about $8 \%$. On average, we find that private label prices are $39 \%$ lower than national brand prices. Private label dollar margins are significantly lower than national brand margins in ten categories whereas the converse is true in about 5 categories. Table 2 presents the store level descriptive 
statistics. The prices and shares of both the national brands and private labels vary across stores. The average number of stores competing with a given store is 6.58 with a standard deviation of 4.30. Not all private labels were introduced at the same time. The Oatmeal category was launched midway in October 1993. ${ }^{[8]}$ For estimation, we use the sales in the observed period as proxy for the entire year. Additionally, we check to see whether excluding this category makes a difference. We find that the main results still hold.

We briefly explain how we calculate the category level averages in Table 1 . We use national brand prices as an example. (The same methodology can be generalized for all other averages in Table 1). We identify the price (dollars per oz. or unit) and dollar sales of each of the national brand UPCs in that specific category in a store, at time $t$. Then we multiply the prices of each of the national brand UPCs by the percentage of national brand sales generated by the respective UPC at time $t$ in the category for a given store and sum them up. This gives us an average national brand price for a given category in a given store at time $t$. We do this for all the stores and time periods. Next, we convert all the prices to a base year (in this case 1993) by adjusting for inflation using the figures published by the Bureau of Labor Statistics. We thus have the inflation-adjusted prices per store per time period. For a given store, we weigh the calculated national brand prices for the category across time, based on the percentage of national brand sales observed. This gives the inflation adjusted time averaged national brand prices for a given store and a given category. We take the standard deviation across stores for a given category (and report it in Table 1). We further weigh the final store prices based on the percentage of national brand sales observed for the stores. As a result, we obtain the average national brand price for a specific category reported in Table 1.

We briefly explain how we calculate the store level averages in Table 2. We use national brand prices as an example (The same methodology can be generalized for all other averages in Table 2). First, we need to find the average national brand price per store per time period. We identify the price (dollars per oz. or unit) and dollar sales of each of the national brand UPCs in a store, at time $t$. Then, in a given store, we multiply the prices of each of the national brand UPCs by the percentage of national brand sales generated by the respective UPC at time $t$ and sum them up. This gives us an average national brand price in a given store at time $t$. We do this for all time periods. Next, we convert all the prices into a base year (in this case 1993) by adjusting for inflation using the figures published by the Bureau of Labor Statistics. We thus have the inflationadjusted prices per store per time period. We take the standard deviation of these figures (and report it in Table 2). Finally, we multiply the percentage of national brand sales generated by each store over all stores with the average national brand price calculated for that respective store and sum these weighted national brand prices up. These average national brand prices are reported in Table 2 (The overall store level average of the national brand prices $N p_{i j t}$ equals 0.164 , see Table 2).

\footnotetext{
${ }^{[8]}$ We include the subcategory of Frozen Pizza which was launched in September 1996 as part of the Frozen Entrees in our analysis. Since private labels were introduced in 1994, the Frozen Entrees category is included only from the year 1994. Nevertheless, we perform additional tests to see the impact of introductions and see that our results are robust.
} 
Table 1

Category Level Descriptive Statistics

\begin{tabular}{|c|c|c|c|c|c|c|c|c|c|}
\hline \multirow[t]{2}{*}{ Category } & \multirow{2}{*}{$\begin{array}{l}\text { Category } \\
\text { \$ Share }\end{array}$} & \multirow{2}{*}{$\begin{array}{l}\text { Private } \\
\text { Label } \\
\$ \\
\text { Share } \\
\%\end{array}$} & \multicolumn{4}{|c|}{$\begin{array}{l}\text { Average Prices } \\
\text { National Brand } \\
\text { Label }\end{array}$} & \multirow{2}{*}{$\begin{array}{l}\begin{array}{l}\text { National } \\
\text { Brand } \\
\text { Margin } \\
\text { (NBM) }\end{array} \\
\$\end{array}$} & \multirow{2}{*}{$\begin{array}{l}\begin{array}{l}\text { Private } \\
\text { Label } \\
\text { Margin } \\
\text { (PLM) }\end{array} \\
\$\end{array}$} & \multirow{2}{*}{$\begin{array}{l}\text { Margin } \\
\text { Difference } \\
\text { (NBM- } \\
\text { PLM) } \\
\$\end{array}$} \\
\hline & & & $\$$ /unit & $\begin{array}{l}\text { Std. } \\
\text { Dev. }\end{array}$ & $\$$ /unit & $\begin{array}{l}\text { Std. } \\
\text { Dev. }\end{array}$ & & & \\
\hline Analgesics & 1.81 & 14.77 & 0.145 & 0.058 & 0.050 & 0.002 & 0.043 & 0.032 & $0.011 *$ \\
\hline Bath Soap & 0.15 & 11.39 & 0.346 & 0.118 & 0.087 & 0.002 & 0.132 & 0.052 & $0.080 * *$ \\
\hline $\begin{array}{l}\text { Bottled } \\
\text { Juice }\end{array}$ & 4.80 & 14.81 & 0.041 & 0.003 & 0.034 & 0.002 & 0.012 & 0.013 & -0.001 \\
\hline $\begin{array}{l}\text { Canned } \\
\text { Soup }\end{array}$ & 4.03 & 3.69 & 0.087 & 0.005 & 0.059 & 0.003 & 0.022 & 0.013 & $0.009 * *$ \\
\hline Cereal & 12.16 & 3.93 & 0.202 & 0.009 & 0.144 & 0.010 & 0.034 & 0.054 & $-0.020^{* *}$ \\
\hline Cookies & 5.80 & 11.12 & 0.187 & 0.018 & 0.107 & 0.015 & 0.052 & 0.044 & $0.008^{*}$ \\
\hline Crackers & 1.71 & 5.57 & 0.198 & 0.031 & 0.096 & 0.007 & 0.058 & 0.049 & $0.009^{*}$ \\
\hline $\begin{array}{l}\text { Dish } \\
\text { Detergent }\end{array}$ & 1.91 & 5.62 & 0.112 & 0.029 & 0.043 & 0.002 & 0.028 & 0.013 & $0.015^{* *}$ \\
\hline $\begin{array}{l}\text { Fabric } \\
\text { Softeners }\end{array}$ & 1.43 & 7.39 & 0.115 & 0.015 & 0.056 & 0.006 & 0.028 & 0.020 & $0.008^{*}$ \\
\hline $\begin{array}{l}\text { Frozen } \\
\text { Entrees }\end{array}$ & 7.17 & 1.02 & 0.198 & 0.010 & 0.180 & 0.018 & 0.070 & 0.062 & $0.008^{*}$ \\
\hline $\begin{array}{l}\text { Frozen } \\
\text { Juice }\end{array}$ & 2.86 & 27.71 & 0.083 & 0.007 & 0.091 & 0.006 & 0.029 & 0.038 & -0.009 \\
\hline Detergents & 6.69 & 2.01 & 0.071 & 0.007 & 0.060 & 0.006 & 0.012 & 0.022 & $-0.010 * *$ \\
\hline Oats & 1.46 & 6.73 & 0.145 & 0.012 & 0.116 & 0.016 & 0.033 & 0.061 & $-0.028 *$ \\
\hline $\begin{array}{l}\text { Paper } \\
\text { Towels }\end{array}$ & 2.73 & 14.71 & 0.912 & 0.096 & 0.565 & 0.057 & 0.149 & 0.175 & $-0.026^{*}$ \\
\hline Razors & 0.88 & 7.89 & 0.876 & 0.065 & 0.318 & 0.040 & 0.248 & 0.224 & 0.024 \\
\hline $\begin{array}{l}\text { Refrgrd. } \\
\text { Juice }\end{array}$ & 7.54 & 16.01 & 0.030 & 0.004 & 0.024 & 0.002 & 0.009 & 0.009 & 0.000 \\
\hline Snacks & 2.94 & 4.33 & 0.245 & 0.016 & 0.138 & 0.005 & 0.070 & 0.060 & $0.010^{*}$ \\
\hline $\begin{array}{l}\text { Soft } \\
\text { Drinks }\end{array}$ & 25.93 & 6.48 & 0.024 & 0.002 & 0.016 & 0.004 & 0.004 & 0.005 & -0.001 \\
\hline $\begin{array}{l}\text { Toilet } \\
\text { Paper }\end{array}$ & 3.87 & 5.80 & 0.387 & 0.027 & 0.335 & 0.046 & 0.052 & 0.089 & $-0.037^{*}$ \\
\hline T. Brushes & 0.49 & 5.59 & 2.151 & 0.278 & 1.367 & 0.125 & 0.868 & 0.896 & -0.028 \\
\hline Toothpaste & 1.52 & 1.57 & 0.521 & 0.056 & 0.302 & 0.043 & 0.148 & 0.115 & 0.033 \\
\hline Tuna & 2.14 & 6.27 & 0.329 & 0.041 & 0.147 & 0.016 & 0.103 & 0.039 & $0.064 * *$ \\
\hline
\end{tabular}

** $p<0.01, * p<0.05$ 
Table 2

Store Level Descriptive Statistics

\begin{tabular}{|c|c|c|c|}
\hline $\begin{array}{l}\text { Variable } \\
\text { Name }\end{array}$ & Description & Average & Std. Dev. \\
\hline$E l_{j}$ & Percent of population over 60 years for store $j$ & 0.176 & 0.063 \\
\hline$E t_{j}$ & Percent of African-American/Hispanic consumers for store $j$ & 0.160 & 0.195 \\
\hline$E d_{j}$ & Percent of college graduates for store $j$ & 0.236 & 0.112 \\
\hline$H v_{j}$ & Percent of houses valued over $\$ 150,000$ around store $j$ & 0.369 & 0.240 \\
\hline$N m_{i j t}$ & National Brand margin of category $i$, store $j$, year $t$ & 0.039 & 0.674 \\
\hline$N p d_{i j t}$ & $\begin{array}{l}\text { National Brand Private Label price difference of category } i \text {, store } j \text {, } \\
\text { year } t\end{array}$ & 0.055 & 0.691 \\
\hline$P p_{i j t}$ & Private Label price of category $i$, store $j$, year $t$ & 0.109 & 0.302 \\
\hline$P L S V_{i j t}$ & Private label sales variation category $i$, store $j$, year $t$ & 0.009 & 0.015 \\
\hline$C S V_{j t}$ & Category sales variation store $j$, year $t$ (in ten thousands) & 20.155 & 70.634 \\
\hline SValue $_{j t}$ & $\begin{array}{l}\text { Dollar Sales of store } j \text {, year } t \text { for the following categories: Grocery } \\
\text { Items, Dairy Foods, Meat Products, Frozen Products, Produce and } \\
\text { Health and Beauty Products (in thousands) }\end{array}$ & 44.172 & 12.745 \\
\hline Week Vol $_{j t}$ & Average weekly volume sales store $j$, year $t$ & 484.589 & 122.952 \\
\hline$C u s C t_{j t}$ & The number of customers visiting store $j$, year $t$ (in thousands) & 2.631 & 0.640 \\
\hline$P S K U_{i j t}$ & $\begin{array}{l}\text { Private Label SKUs as a fraction of the total SKUs per category } i \text {, } \\
\text { store } j, \text { year } t\end{array}$ & 11.6287 & 0.0780 \\
\hline$E D L P_{i j t}$ & $\begin{array}{l}\text { Variation in total volume sold on promotion across weeks per } \\
\text { category } i \text {, store } j \text {, for year } t\end{array}$ & 3.945 & 0.0225 \\
\hline Assort $_{i j t}$ & Average Number of SKUs per category $i$, store $j$, year $t$ & 134.505 & 109.154 \\
\hline$C D I_{i j t}$ & $\begin{array}{l}\text { National Brand volume share variation across weeks for category } i \text {, } \\
\text { store } j \text {, year } t\end{array}$ & 3.27 & 0.93 \\
\hline Npromo $_{i j t}$ & National Brands sold on promotion for category $I$, store $j$, year $t$ & 6.172 & 6.990 \\
\hline Ppromo $_{i j t}$ & Private labels sold on promotion for category $i$, store $j$, year $t$ & 27.138 & 12.768 \\
\hline $\operatorname{VarNSKU} U_{i j t}$ & $\begin{array}{l}\text { Variance in national brand SKUs across weeks, category } i \text {, store } j \text {, } \\
\text { year } t\end{array}$ & 257.553 & 1352.243 \\
\hline$H n_{j}$ & Total number of households served by store $j$ (in thousands) & 15.205 & 7.982 \\
\hline$P L_{i j t}$ & Private Label share of category $i$, store $j$, year $t$ & 7.666 & 7.146 \\
\hline$N p_{i j t}$ & National Brand price of category $i$, store $j$, year $t$ & 0.164 & 0.835 \\
\hline Density $_{j t}$ & Trading area in square miles per capita for store $j$, year $t$ & 0.001 & 0.0009 \\
\hline Shpcons $_{j t}$ & Percentage of constrained shoppers for store $j$, year $t$ & 8.290 & 6.225 \\
\hline Cubdist $_{j t}$ & Distance to the nearest club warehouse for store $j$, year $t$ & 6.197 & 3.678 \\
\hline Poverty $_{j t}$ & Percent of population earning $\$ 15,000$ or less store $j$, year $t$ & 5.792 & 4.523 \\
\hline$S_{. j t}$ & Total number of competing stores (all categories) store $j$, year $t$ & 6.580 & 4.300 \\
\hline
\end{tabular}


We first perform two independent causality tests on $(i)$ national brand margins and private label market shares and ( $i$ ) private label market shares and number of competing stores. Based on the results we obtain from $(i)$ and $(i i)$, we construct and estimate a joint model. We control for other factors to better capture the store level variation. Finally, we discuss alternative explanations.

We begin our analysis by performing Granger causality tests (Hamilton 1994). We present the models in Table 3. $P L_{i j t}$ denotes the private label share for category $i$ in store $j$ for year $t, N m_{i j t}$ is the corresponding national brand margin and $S_{. j t}$ represents the total number of competing stores against store $j$ during time $t$. Some of the variables, i.e. $P L_{i j t}$, are category specific. We assume that all the stores carry all the categories. We use $S_{. j t}$ in our exposition for clarity.

Table 3

\section{Causality analyses}

\begin{tabular}{|c|c|}
\hline $\begin{array}{l}\text { Model 1: Private label market share versus } \\
\text { national brand margin }\end{array}$ & $\begin{array}{l}\text { Model 2: Private label market share versus } \\
\text { number of competing stores }\end{array}$ \\
\hline$P L_{i j t}=a_{i j}^{1}+b^{1} P L_{i j, t-1}+c^{1} N m_{i j, t-1}+\varepsilon_{i j t}$ & $P L_{i j t}=a_{i j}^{2}+b^{2} P L_{i j, t-1}+c^{2} S_{. j, t-1}+\varepsilon_{i j t}^{\prime}$ \\
\hline$N m_{i j t}=d_{i j}^{1}+e^{1} N m_{i j, t-1}+f^{1} P L_{i, t, t-1}+\xi_{i j t}$ & $S_{. j t}=d_{i j}^{2}+e^{2} S_{. j, t-1}+f^{2} P L_{i j, t-1}+\zeta_{i j t}^{\prime}$ \\
\hline
\end{tabular}

Estimates (standard deviations) of the models $* * *$

\begin{tabular}{|c|c|c|c|}
\hline \multicolumn{2}{|l|}{ Model 1**** } & \multicolumn{2}{|l|}{ Model 2****** } \\
\hline Parameter & $\begin{array}{l}\text { Estimates } \\
\text { (Std.Dev.) }\end{array}$ & Parameter & $\begin{array}{l}\text { Estimates } \\
\text { (Std.Dev.) }\end{array}$ \\
\hline$a_{i j}^{1}($ Intercept $)$ & $\begin{array}{l}2.067 * \\
(0.932)\end{array}$ & $a_{i j}^{2}($ Intercept $)$ & $\begin{array}{l}3.981 * * \\
(1.091)\end{array}$ \\
\hline$b^{1}$ (Private Labels $P L_{i j, t-1}$ ) & $\begin{array}{l}0.282 * * \\
(0.012)\end{array}$ & $b^{2}$ (Private Labels $\left.P L_{i j, t-1}\right)$ & $\begin{array}{l}0.097 * * \\
(0.020)\end{array}$ \\
\hline$c^{1}$ (National Brand Margin $\left.N m_{i j, t-1}\right)$ & $\begin{array}{l}7.260 * * \\
(0.926) \\
\end{array}$ & $\begin{array}{l}c^{2} \text { (Number of competing stores } \\
\left.S_{. j, t-1}\right)\end{array}$ & $\begin{array}{l}-0.003 \\
(0.020)\end{array}$ \\
\hline$d_{i j}^{1}($ Intercept $)$ & $\begin{array}{l}0.137 * * \\
(0.012)\end{array}$ & $d_{i j}^{2}($ Intercept $)$ & $\begin{array}{l}1.722 \\
(2.176)\end{array}$ \\
\hline$e^{1}$ (National Brand Margin $\left.N m_{i j, t-1}\right)$ & $\begin{array}{l}0.109 * * \\
(0.011) \\
\end{array}$ & $\begin{array}{l}e^{2} \text { (Number of competing stores } \\
\left.S_{\cdot j, t-1}\right)\end{array}$ & $\begin{array}{l}0.705^{* *} \\
(0.040) \\
\end{array}$ \\
\hline$f^{1}$ (Private Labels $P L_{i j, t-1}$ ) & $\begin{array}{l}-0.120 \\
(0.146)\end{array}$ & $f^{2}$ (Private Labels $P L_{i j, t-1}$ ) & $\begin{array}{l}-0.061 * \\
(0.030)\end{array}$ \\
\hline MSE & 5.60 & MSE & 8.70 \\
\hline $\begin{array}{l}\text { Number of parameters }- \text { intercepts } \\
\text { - coefficients }\end{array}$ & $\begin{array}{l}3298 \\
4\end{array}$ & $\begin{array}{l}\text { Number of parameters - intercepts } \\
\text { - coefficients }\end{array}$ & $\begin{array}{l}3298 \\
4\end{array}$ \\
\hline Number of observations ${ }^{2}$ & 6525 & Number of observations ${ }^{3}$ & 4950 \\
\hline
\end{tabular}

$* * p<0.01, * p<0.05$

*** We estimate a fixed effects model to account for store-category effects. We thus have $(22 x 75-1)=1649$ intercept and 2 coefficients (for the independent variables) which equals 1651 parameter estimates for each equation; there are two equations for each model.

**** For Model 1, we use observations for 22 categories, 75 stores and for a period of 4 years (1994-1997). However, for the entrees category, we do not have data on private label shares for the year 1993. As we cannot lag values for 1994, this category year is dropped. We thus end up with $(22 * 75 * 4)-75=6525$ observations.

***** For Model 2, we have complete observations for 22 categories, 75 stores and 3 years (since we use a lagged variable representing the number of competing stores, we loose one year in Model 2), resulting in a total of 4950 observations. 
In Model 1, we check the causality between private label market shares and national brand margins. A significant $c^{1}$ coefficient, coupled with a non-significant $f^{1}$ coefficient suggests that national brand margins influence private label market shares, not the other way around. Similarly, in Model 2, we check the causality between private label market shares and the number of competing stores. A significant $f^{2}$ coefficient, coupled with a non-significant $c^{2}$ coefficient suggests that private label market shares cause changes in the number of competing stores.

As indicated in Table 3, we find that national brand margins positively impact private label shares and not vice versa. Also, private label market shares cause decreases in the number of competing stores and not the other way around. When we perform the Granger causality test using two lags, we find that the results are similar but the model does not significantly improve. For brevity, we do not include the results.

Following this, we set up a joint model to test the significance between national brand margin and private label market share, and between private label market share and number of competing stores. To account for possible store-category level differences, we use other variables that have been used by Dhar and Hoch (1997). Please refer to Table 2 for the descriptive statistics.

The first equation (Equation 9) captures the private label market share in category $i$, store $j$ during time $t\left(P L_{i j t}\right)$. The key independent variables are the previous year's national brand margins $\left(N m_{i j, t-1}\right)$. Following Dhar and Hoch (1997), we include retail level factors such as retail competition, economies of scale, economies of scope, pricing format, depth of assortment, category development index, national brand promotions and private label promotions in our analysis. In addition, we also include manufacturer level factors such as brand competition $\left(\operatorname{VarNSKU}_{i j t}\right)$. Since the number of private label SKUs $\left(P S K U_{i j t}\right)$ and national brand SKUs are negatively correlated, we could not include both variables at the same time. The definitions of the variables are provided in Table 2. In the second equation (Equation 10), we capture determinants of the number of stores in the market. The key variable of interest is the impact of the private label market share $\left(P L_{i j t}\right)$ on the number of stores $\left(S_{. j, t+1}\right)$. Other variables included are those likely to impact market potential such as the number of households $\left(H n_{j}\right)$, population density in the zip code $\left(\right.$ Density $\left._{j t}\right)$, level of poverty $\left(\right.$ Poverty $\left._{j t}\right)$, percentage of constrained shoppers $\left(\right.$ Shpcons $\left._{j t}\right)$ and distance from nearest club/warehouse $\left(C u b d i s t_{j t}\right)$. We also include national brand prices $\left(N p_{i j t}\right)$ as an indicator of the level of price competition. If private labels do affect competition as predicted by the model, we expect $\beta_{2}$ to be negative. Moreover, if stores behave strategically to take advantage of their private label sales, we expect $\alpha_{5}$ to be positive. 


$$
\begin{aligned}
P L_{i j t}= & \alpha_{0}+\alpha_{1} E l_{j}+\alpha_{2} E t_{j}+\alpha_{3} E d_{j}+\alpha_{4} H v_{j}+\alpha_{5} \text { Nm }_{i j, t-1}+\alpha_{6} \text { Npd }_{i j t}+\alpha_{7} P p_{i j t}+\alpha_{8} P L S V_{i j t} \\
& +\alpha_{9} \text { CSV }_{j t}+\alpha_{10} \text { SValue }_{j t}+\alpha_{11} \text { WeekVol }_{j t}+\alpha_{12} \text { CuSCt }_{j t}+\alpha_{13} \text { PSKU }_{i j t}+\alpha_{14} \text { EDLP }_{i j t} \\
& +\alpha_{15} \text { Assort }_{i j t}+\alpha_{16} \text { CDI }_{i j t}+\alpha_{17} \text { Npromo }_{i j t}+\alpha_{18} \text { Ppromo }_{i j t}+\alpha_{19} \text { VarNSKU }_{i j t}+\varepsilon_{i j t}, \\
S_{. j, t+1}= & \beta_{0}+\beta_{1} H_{j}+\beta_{2} \text { PL }_{i j t}+\beta_{3} \text { Np }_{i j t}+\beta_{4} \text { Density }_{j t}+\beta_{5} \text { Shpons }_{j t}+\beta_{6} \text { Cubdist }_{j t}+\beta_{7} \text { Poverty }_{j t}+e_{i j, t+1}
\end{aligned}
$$

We estimate the equations ( 9 and 10) jointly using a generalized method of moments (GMM). We do not include the private label costs in Equation (9) since private label costs and prices are highly correlated $(\rho=0.9)$. As independent variables such as the brand margins and prices may be correlated with the error terms, we use lagged values of the above variables as instruments (Hamilton, 1994). To check the robustness of the estimates we use other instrument variables similar to Nevo (2000) and Chintagunta, Bonfrer and Song (2002). The analysis indicates that the results are robust. We present the results in Table 4. As predicted $\beta_{2}$ is significantly negative $(p<0.01)$ and $\alpha_{5}$ is significantly positive $(p<0.01)$ providing support for the model predictions.

We also test for the robustness of the results to the categorization of stores based on the number of employees. We reanalyze the data using only stores with more than $20\left(\beta_{2}=-0.043 p<.01 ; \alpha_{5}=37.94 p<0.0001\right)$ or more than $100\left(\beta_{2}=-0.09 p<0.10 ; \alpha_{5}\right.$ $=40.79 p<0.0001)$ employees and find similar results. While the number of stores is one indicator of the level of competition in a market, we also check for the robustness of the results using alternate measures of competitiveness of a market. We use category sales variation to capture the competitiveness of the stores (e.g., Dhar and Hoch, 1997) where higher category sales variation implies a more competitive environment. We calculate the mean category volume variation per store per year across the stores. Using this mean, we split the stores into two groups based on whether they are above this mean or below this mean. Then the joint equation is estimated for each group. The results are presented in Table 5. Again, the key coefficients have the expected signs, $\alpha_{5}$ positive and $\beta_{2}$ negative. For above mean variation stores, we find $\beta_{2}=-0.055 p<.05$, $\alpha_{5}=37.38 p<0.0001$. For below mean variation stores, we find $\beta_{2}=-0.07 p<0.1, \alpha_{5}$ $=40.05 p<0.0001$.

A limitation of this analysis is that we have access to data from only one grocery chain. To account for the effects of major competitors, we examine if the results are similar based in zip codes where DFF faces easier or tougher competition. Following the logic of Dhar and Hoch (1997), we use temporal heterogeneity in private label shares as an indicator of competitiveness. We then classify the zip codes as high or low competitiveness and reanalyze the data. The estimates (provided in Table 6) indicate that the results are robust to the level of competitiveness. $\alpha_{5}$ is positive and $\beta_{2}$ is negative and significant. 
Table 4

Results of the Joint Model

\begin{tabular}{|c|c|c|c|}
\hline Parameter & Expected Sign & Coeff. & t-stat \\
\hline$\alpha_{0}($ Intercept $)$ & n.a. & 0.10 & 0.99 \\
\hline$\alpha_{1}\left(\right.$ Elderly $\left.E l_{j}\right)$ & + & 2.24 & 1.44 \\
\hline$\alpha_{2}\left(\right.$ Ethnicity $\left.E t_{j}\right)$ & + & -0.89 & -1.63 \\
\hline$\alpha_{3}\left(\right.$ Education $\left.E d_{j}\right)$ & + & 2.92 & 1.61 \\
\hline$\alpha_{4}\left(\right.$ House value $\left.H v_{j}\right)$ & - & -4.37 & -5.63 \\
\hline$\alpha_{5}\left(\mathrm{NB}\right.$ margin $\left.N m_{i j t}\right)$ & + & 37.29 & 19.85 \\
\hline$\alpha_{6}\left(\right.$ NB-PL price diff. $\left.N p d_{i j t}\right)$ & + & 7.03 & 9.81 \\
\hline$\alpha_{7}\left(\right.$ PL price $\left.P p_{i j t}\right)$ & - & -14.71 & 12.26 \\
\hline$\alpha_{8}\left(\right.$ PL sales variation $\left.P L S V_{i j t}\right)$ & - & -3.59 & -0.33 \\
\hline$\alpha_{9}\left(\right.$ Category sales variation $\left.C S V_{j t}\right)$ & + & 0.0129 & 3.24 \\
\hline$\alpha_{10}\left(\right.$ Sales value $\left._{\text {SValue }}{ }_{j t}\right)$ & + & -0.05 & -4.55 \\
\hline$\alpha_{11}\left(\right.$ Weekly volume WeekVol $\left._{j t}\right)$ & + & 0.006 & 0.72 \\
\hline$\alpha_{12}\left(\right.$ Customer count $\left.C u s C t_{j t}\right)$ & + & 5.32 & 2.32 \\
\hline$\alpha_{13}$ (Private label SKU PSKU $U_{i j t}$ ) & + & 27.89 & 11.67 \\
\hline$\alpha_{14}\left(\right.$ Pricing format $\left.E D L P_{i j t}\right)$ & - & -82.38 & -16.58 \\
\hline$\alpha_{15}\left(\right.$ Assortment Assort $\left._{i j t}\right)$ & - & -0.005 & -7.48 \\
\hline$\alpha_{16}\left(\right.$ NB Category expertise $\left.C D I_{i j t}\right)$ & + & 0.24 & 1.03 \\
\hline$\alpha_{17}\left(\mathrm{NB}\right.$ promo Npromo $\left._{i j j}\right)$ & + & 55.10 & 20.30 \\
\hline$\alpha_{18}\left(\right.$ PL promo Ppromo $\left.o_{i j t}\right)$ & - & -5.53 & -3.79 \\
\hline$\alpha_{19}\left(\right.$ NB SKU variance $\left.\operatorname{Var} N S K U_{i j t}\right)$ & + & 0.0001 & 3.84 \\
\hline$\beta_{0}$ (Intercept) & n.a. & 4.48 & 13.78 \\
\hline$\beta_{1}\left(\#\right.$ of Households $\left.H n_{j}\right)$ & + & 0.0003 & 40.04 \\
\hline$\beta_{2}\left(\mathrm{PL}\right.$ share $\left.P L_{i j t}\right)$ & - & -0.066 & -3.04 \\
\hline$\beta_{3}\left(\mathrm{NB}\right.$ price $\left.N p_{i j t}\right)$ & + & 0.28 & 0.55 \\
\hline$\beta_{4}\left(\right.$ Density Density $\left.{ }_{j t}\right)$ & + & 219.21 & 3.44 \\
\hline$\beta_{5}\left(\right.$ Constrained Shoppers Shpcons $\left._{j t}\right)$ & + & -3.89 & -0.34 \\
\hline$\beta_{6}\left(\right.$ Cubdist Cubdist $\left._{j t}\right)$ & + & -0.168 & -0.87 \\
\hline$\beta_{7}\left(\right.$ Poverty Poverty $\left.{ }_{j t}\right)$ & + & 0.03 & 0.00 \\
\hline MSE & \multicolumn{3}{|c|}{41.56} \\
\hline Number of Parameters & \multicolumn{3}{|c|}{28} \\
\hline Number of Observations & \multicolumn{3}{|c|}{8175} \\
\hline
\end{tabular}


Table 5

Results of the Joint Model for Above/Below Mean Sales Variation

\begin{tabular}{|c|c|c|c|c|c|}
\hline \multirow[b]{2}{*}{ Parameter } & \multicolumn{3}{|c|}{$\begin{array}{c}\text { Above mean } \\
\text { variation }\end{array}$} & \multicolumn{2}{|c|}{ Below mean variation } \\
\hline & $\begin{array}{l}\text { Expected } \\
\text { Sign }\end{array}$ & Coeff. & t-stat & Coeff. & t-stat \\
\hline$\alpha_{0}($ Intercept $)$ & n.a. & 0.11 & 0.08 & -3.73 & -2.97 \\
\hline$\alpha_{1}\left(\right.$ Elderly $\left.E l_{j}\right)$ & + & 3.30 & 1.75 & 2.71 & 1.59 \\
\hline$\alpha_{2}\left(\right.$ Ethnicity $\left.E t_{j}\right)$ & + & -1.58 & -2.29 & -0.73 & -1.19 \\
\hline$\alpha_{3}\left(\right.$ Education $\left.E d_{j}\right)$ & + & 2.76 & 1.34 & 3.04 & 1.48 \\
\hline$\alpha_{4}\left(\right.$ House value $\left.H v_{j}\right)$ & - & -4.45 & -4.85 & -4.33 & -4.98 \\
\hline$\alpha_{5}\left(\mathrm{NB}\right.$ margin $\left.N m_{i j t}\right)$ & + & 37.38 & 14.89 & 40.05 & 21.59 \\
\hline$\alpha_{6}$ (NB-PL price diff. $\left.N p d_{i j t}\right)$ & + & 10.03 & 10.90 & 4.01 & 5.15 \\
\hline$\alpha_{7}\left(\mathrm{PL}\right.$ price $\left.P p_{i j t}\right)$ & - & -14.67 & -10.56 & -17.74 & 17.11 \\
\hline$\alpha_{8}\left(\right.$ PL sales variation $\left.P L S V_{i j t}\right)$ & - & 47.59 & 2.86 & -43.91 & -5.05 \\
\hline$\alpha_{9}\left(\right.$ Category sales variation $\left.C S V_{j t}\right)$ & + & 0.005 & 2.39 & 0.003 & 12.69 \\
\hline$\alpha_{10}\left(\right.$ Sales value $\left._{\text {SValue }}{ }_{j t}\right)$ & + & -0.05 & -3.51 & -0.05 & -3.18 \\
\hline$\alpha_{11}\left(\right.$ Weekly volume WeekVol $\left._{j t}\right)$ & + & 0.96 & 1.08 & 1.21 & 1.18 \\
\hline$\alpha_{12}\left(\right.$ Customer count $\left.C u s C t{ }_{j t}\right)$ & + & 0.74 & 2.60 & 0.17 & 0.60 \\
\hline$\alpha_{13}\left(\right.$ Private label SKU $\left.P S K U_{i j t}\right)$ & + & 18.47 & 6.62 & 40.76 & 16.09 \\
\hline$\alpha_{14}\left(\right.$ Pricing format $\left.E D L P_{i j t}\right)$ & - & -81.67 & -9.62 & -80.06 & -15.22 \\
\hline$\alpha_{15}\left(\right.$ Assortment Assort $\left._{i j t}\right)$ & - & 0.007 & 8.50 & 0.004 & 5.56 \\
\hline$\alpha_{16}\left(\right.$ NB Category expertise $\left.C D I_{i j t}\right)$ & + & 0.50 & 3.13 & 0.29 & 2.15 \\
\hline$\alpha_{17}\left(\right.$ NB promo Npromo $\left._{i j t}\right)$ & + & 60.45 & 16.33 & 48.67 & 17.58 \\
\hline$\alpha_{18}\left(\right.$ PL promo Ppromo $\left._{i j t}\right)$ & - & -2.24 & -1.16 & -5.42 & -4.11 \\
\hline$\alpha_{19}\left(\mathrm{NB} S K U\right.$ variance $\left.\operatorname{Var} N S K U_{i j t}\right)$ & + & 0.00007 & 1.99 & 0.0005 & 7.25 \\
\hline$\beta_{0}($ Intercept $)$ & n.a. & 4.17 & 9.35 & 4.31 & 12.35 \\
\hline$\beta_{1}$ (\# of Households $H n_{j}$ ) & + & 0.0004 & 28.80 & 0.0003 & 32.64 \\
\hline$\beta_{2}\left(\mathrm{PL}\right.$ share $\left.P L_{i j t}\right)$ & - & -0.055 & -1.98 & -0.07 & -1.92 \\
\hline$\beta_{3}\left(\mathrm{NB}\right.$ price $\left.N p_{i j t}\right)$ & + & 0.113 & 0.20 & 0.182 & 0.41 \\
\hline$\beta_{4}\left({\left.\text { Density } \text { Density }_{j t}\right)}\right.$ & + & 26.26 & 2.99 & 19.15 & 2.42 \\
\hline$\beta_{5}\left(\right.$ Constrained Shoppers Shpcons $\left.{ }_{j t}\right)$ & + & 6.78 & 0.41 & -12.95 & -0.94 \\
\hline$\beta_{6}\left(\right.$ Cubdist Cubdist $\left._{j t}\right)$ & + & -0.16 & -5.61 & -0.16 & -6.57 \\
\hline$\beta_{7}\left(\right.$ Poverty Poverty $\left.{ }_{j t}\right)$ & + & -15.25 & -0.68 & 11.83 & 0.63 \\
\hline MSE & \multicolumn{3}{|c|}{45.32} & \multicolumn{2}{|c|}{38.50} \\
\hline Number of Parameters & \multicolumn{3}{|c|}{28} & \multicolumn{2}{|c|}{28} \\
\hline Number of Observations & \multicolumn{3}{|c|}{3825} & \multicolumn{2}{|c|}{4350} \\
\hline
\end{tabular}


Table 6

Results of the Joint Model for Above/Below Mean Private Label Share Variation

\begin{tabular}{|c|c|c|c|c|c|}
\hline \multirow[b]{2}{*}{ Parameter } & \multicolumn{3}{|c|}{$\begin{array}{c}\text { Above mean } \\
\text { variation }\end{array}$} & \multicolumn{2}{|c|}{ Below mean variation } \\
\hline & $\begin{array}{l}\text { Expected } \\
\text { Sign } \\
\end{array}$ & Coeff. & t-stat & Coeff. & t-stat \\
\hline$\alpha_{0}$ (Intercept) & n.a. & -2.76 & -1.88 & 3.13 & 2.15 \\
\hline$\alpha_{1}\left(\right.$ Elderly $\left.E l_{j}\right)$ & + & -3.18 & -2.34 & -1.17 & -0.88 \\
\hline$\alpha_{2}\left(\right.$ Ethnicity $\left.E t_{j}\right)$ & + & -1.90 & -3.55 & 0.21 & 0.41 \\
\hline$\alpha_{3}\left(\right.$ Education $\left.E d_{j}\right)$ & + & 3.70 & 2.42 & 1.85 & 1.23 \\
\hline$\alpha_{4}\left(\right.$ House value $\left.H v_{j}\right)$ & - & -5.10 & -7.81 & -2.82 & -4.39 \\
\hline$\alpha_{5}\left(\mathrm{NB}\right.$ margin $\left.N m_{i j t}\right)$ & + & 56.91 & 23.04 & 10.61 & 6.22 \\
\hline$\alpha_{6}$ (NB-PL price diff. $\left.N p d_{i j t}\right)$ & + & 9.31 & 7.38 & 5.46 & 4.71 \\
\hline$\alpha_{7}\left(\right.$ PL price $\left.P p_{i j t}\right)$ & - & -25.95 & -20.25 & -11.91 & -2.41 \\
\hline$\alpha_{8}\left(\right.$ PL sales variation $\left.P L S V_{i j t}\right)$ & - & -21.45 & -2.05 & 63.75 & 3.64 \\
\hline$\alpha_{9}\left(\right.$ Category sales variation $\left.C S V_{j t}\right)$ & + & 0.003 & 10.35 & 0.0002 & 1.96 \\
\hline$\alpha_{10}\left(\right.$ Sales value SValue $\left._{j t}\right)$ & + & -0.15 & -8.13 & 0.008 & 0.62 \\
\hline$\alpha_{11}\left(\right.$ Weekly volume WeekVol $_{j t}$ ) & + & 0.002 & 2.14 & 0.0003 & 0.39 \\
\hline$\alpha_{12}\left(\right.$ Customer count $\left.C u s C t_{j t}\right)$ & + & 1.36 & 4.83 & -3.32 & -1.17 \\
\hline$\alpha_{13}\left(\right.$ Private label SKU PSKU $\left.U_{i j t}\right)$ & + & 38.43 & 14.38 & 11.17 & 2.65 \\
\hline$\alpha_{14}\left(\right.$ Pricing format $\left.E D L P_{i j t}\right)$ & - & -106.84 & -14.87 & -46.46 & -6.73 \\
\hline$\alpha_{15}$ (Assortment Assort $_{i j t}$ ) & - & -0.008 & -8.83 & -0.002 & -0.85 \\
\hline$\alpha_{16}\left(\right.$ NB Category expertise $\left.C D I_{i j t}\right)$ & + & -0.04 & -0.34 & 0.52 & 2.90 \\
\hline$\alpha_{17}\left(\right.$ NB promo Npromo $\left._{i j t}\right)$ & + & 42.13 & 15.56 & 86.12 & 18.05 \\
\hline$\alpha_{18}\left(\right.$ PL promo Ppromo $\left._{i j t}\right)$ & - & -7.09 & -3.60 & -3.61 & -1.83 \\
\hline$\alpha_{19}\left(\right.$ NB SKU variance $\left.\operatorname{Var} N S K U_{i j t}\right)$ & + & -0.002 & -0.05 & 0.003 & 1.42 \\
\hline$\beta_{0}($ Intercept $)$ & n.a. & 3.71 & 17.22 & 4.03 & 19.21 \\
\hline$\beta_{1}$ (\# of Households $H n_{j}$ ) & + & 0.004 & 59.01 & 0.0004 & 54.95 \\
\hline$\beta_{2}\left(\mathrm{PL}\right.$ share $\left.P L_{i j t}\right)$ & - & -0.049 & -3.18 & -0.06 & -3.96 \\
\hline$\beta_{3}\left(\mathrm{NB}\right.$ price $\left.N p_{i j t}\right)$ & + & 0.54 & 1.42 & -0.10 & -0.24 \\
\hline$\beta_{4}\left(\right.$ Density Density $\left.{ }_{j t}\right)$ & + & 30.04 & 8.21 & 30.39 & 7.79 \\
\hline$\beta_{5}\left(\right.$ Constrained Shoppers Shpcons $\left._{j t}\right)$ & + & 17.19 & 2.13 & 14.20 & 1.66 \\
\hline$\beta_{6}\left(\right.$ Cubdist $\left.C u b d i s t_{j t}\right)$ & + & -0.16 & -14.95 & -0.16 & -14.50 \\
\hline$\beta_{7}\left(\right.$ Poverty Poverty $\left.{ }_{j t}\right)$ & + & -31.18 & -2.86 & -26.83 & -2.33 \\
\hline MSE & \multicolumn{3}{|c|}{41.25} & \multicolumn{2}{|c|}{40.38} \\
\hline Number of Parameters & \multicolumn{3}{|c|}{28} & \multicolumn{2}{|c|}{28} \\
\hline Number of Observations & \multicolumn{3}{|c|}{4175} & \multicolumn{2}{|c|}{4000} \\
\hline
\end{tabular}


Second, another concern is that the significance of the parameters, particularly $\beta_{2}$, is due to the increased consumer price sensitivity during the analysis period; i.e., adverse economic conditions simultaneously lead to increased price sensitivities and store closings. To rule out this explanation, we perform three analyses.

First, if the change in the number of stores is due to the increased price sensitivities, then we should observe some relationship between the price elasticities and the number of stores in a particular region. More specifically, the price elasticities (of both national and store brands) associated with a particular zip code should be negatively correlated with the number of stores operating in that zip code. In other words, if adverse economic conditions are causing consumers to become more price sensitive and result in the store closings, we should find fewer stores in zip codes which have higher price elasticities. To analyze the above relationship, we performed a regression analysis using price elasticity as a dependent variable and the number of stores and other variables as independent variables. We found that the relationship between the price elasticity and the number of stores operating in a particular zip code is not significant ( $p$ value $=0.89$ ).

Second, since retail stores will strategically react to the increases in consumer price sensitivities, we should expect to see a relationship between the change in price elasticities associated with a particular zip code over the years and the change in the number of retail stores operating in the zip code during the corresponding periods. We, however, do not find any such significant relationship in the data. (Moreover, there is no consistent pattern for changes in price elasticities across categories over the data period.)

Third, we should expect to see the same result (i.e. a negative and significant $\beta_{2}$ ) even in the short run if consumer price sensitivities are causing the above result. We replicate the estimation of Equation (9) and Equation (10) without the lag (in this case, the dependent variable in Equation (10) becomes $S_{j, t}$ instead of $S_{j, t+1}$ ). When we do not use a lag, the parameter estimate $\beta_{2}$ is not significant. Therefore, we rule out the explanation that the adverse economic conditions drive the results.

Another possible explanation is that it is a spurious relationship caused by an unobservable variable such as good managers driving both high private label shares and competitive store closings. We control for such unobservable factors by first differencing the data (e.g., Boulding and Staelin, 1990). The effect of private labels on the number of competitors is still significant.

\section{Conclusion}

Typically, research in retailing has examined strategies from the perspective of maximizing store profitability (Inman and McAlister, 1993; Mulhern and Leone, 1991), category profitability (Chintagunta, 2002), store switching (Bell, Iyer and Padmanabhan, 2002; Kumar and Leone, 1988), store price judgments and store image (Alba et al., 1999). However, by minimizing and thwarting competition, a firm can come close to achieving monopoly profits. One of the major goals of firms, therefore, is to design marketing strategies that would lead competitors to reduce their propensity to enter/exit the market. In this paper, we show that increasing private label sales can also serve this anti-competitive objective. 
Several researchers in economics and marketing have examined the strategies employed by firms to minimize competitiveness by achieving entry deterrence (e.g., Dixit, 1980; Spence, 1977). Prior studies have considered the strategic role in competition of offering many branded variants (Bergen, Dutta and Shugan, 1996; Srinivasan, 1991), advertising and R\&D (Kadiyali, 1996; Fudenberg and Tirole, 1984; Schmalansee, 1983). Other forms of capital accumulation for deterring entry include setting up exclusive franchises and developing loyal clienteles (Tirole, 1988). We add to this literature by identifying private labels as another device that can be used strategically. Thus, we identify another benefit of private labels.

Besides private labels, retailers can decrease the attractiveness of the marketing by increasing the costs of entering the market through increased advertising or improved service levels or by decreasing price levels. Unlike other strategic variables to reduce competition, we believe that private labels provide two benefits to thwart competition. First, private labels are unique to the retailer and therefore provide differentiating benefits that are difficult to replicate. Second, private labels may increase loyalty.

Consistent with earlier research (Hoch and Banerji, 1993; Ailawadi and Harlam, 2004; Chintagunta, Bonfrer and Song, 2002), we find a positive relationship between national brand margins and private label shares. The main argument in the literature has been that retailers with high private label shares are able to elicit higher concessions from the manufacturers. Increased profitability due to high national brand margins can make the market susceptible to stronger competition. Increasing private label share to counteract market attractiveness also explains the link with high national brand margins.

Dhar and Hoch (1997) also find a negative relationship between the private label market share and the number of competitors. They conjecture that stores facing low competition have the luxury of experimenting with private labels. While the DFF dataset supports our proposed strategic role of private labels to reduce competition, other explanations merit further empirical research.

At a broader level, more generalizations are needed about the competitive impact of private labels. There is some empirical evidence that increasing private label sales can lead to anticompetitive effects. Ward et al. (2002) find that in several categories, increasing private label sales are associated with higher national brand prices and also lower frequency of promotions. Using a panel data of milk purchase, Bonanno and Lopez (2005) find that increased private label sales increase national brand prices, but more importantly, the price of private label milk also increases as the share of private label increases. While private labels may enhance supermarket profitability, the effect on social welfare and competition needs further exploration.

\section{References}

Ailawadi, K.L., Gedenk, K., and Neslin, S. (2001). "Pursuing the Value Conscious Consumer: Private Labels versus National Brand Promotions," Journal of Marketing, 65: 71-89.

Ailawadi, K.L. and Harlam, B.A. (2004). "An Empirical Analysis of Retail Margins: The Role of Store Brands," Journal of Marketing, 68: 147-165. 
Alba, J.W., Mela, C.F., Shimp, T.A., and Urbany, J.E. (1999). “The Effect of Discount Frequency and Depth on Consumer Price Judgments," Journal of Consumer Research, 26: 99-114.

Bell, D.R., Iyer, G., and Padmanabhan, V. (2002). "Price Competition Under Stockpiling and Flexible Consumption," Journal of Marketing Research, 39: 292- 303.

Blattberg, R.C., and Wisniewski, K J. (1989). "Price-Induced Patterns of Competition," Marketing Science, 8: 291-309.

Bonanno, A., and Lopez, R.A. (2005). "Private Label Expansion and Supermarket Milk Prices," Journal of Agriculture and Food Industrial Organization, 3: 1085.

Bergen, M., Dutta, S., and Shugan, S.M. (1996). "Branded Variants: A Retail Perspective," Journal of Marketing Research, 33: 9-19.

Boulding, W. and Staelin, R. (1990). "Environment, Market Share, Market Power," Management Science, 36: 1160-1177.

Bucklin, R.E. and Srinivasan, V. (1991). "Determining Interbrand Substitutability through Survey Measurement of Consumer Preference Structures," Journal of Marketing Research, 28: 58-71.

Chain Store Age, (2005). "Reinventing Supermarkets,” July, 81: 28.

Chintagunta, P.K. (2002). "Investigating Category Pricing Behavior at a Retail Chain," Journal of Marketing Research, 39: 141-154.

Chintagunta, P.K., Bonfrer, A., and Song, I. (2002). "Investigating the Effects of Store-Brand Introduction on Retailer Demand and Pricing Behavior," Management Science, 48: 1242-1268.

Corstjens, M. and Lal, R. (2000). "Building Store Loyalty Through Store Brands," Journal of Marketing Research, 37: 281-291.

Dhar, S.K. and Hoch, S.J. (1997). "Why Store Brand Penetration Varies by the Retailer," Marketing Science, 16: 208-227.

Dixit, A. (1980). “The Role of Investment in Entry-Deterrence,” Economic Journal, 90: 95-106.

Friedman, J. (1979). On Entry Preventing Behavior and Applied Game Theory. Vienna: Physica Verlag.

Fudenberg, D. and Tirole, J. (1984). "The Fat-Cat Effect, The Puppy-Dog Ploy, and the Lean and Hungry Look," American Economic Review, 74: 361-366.

FMI, (2003). "Building Shopper Loyalty With Store Brands," Available [online] at: www.fmi.org/pub.

-----, (2010). “The Food Retailing Industry Speaks 2010," Available [online] at: http://www.fmi.org/forms/store/ProductFormPublic/search?action=1\&Product_productNumber=2318.

Hamilton, J.D. (1994). Time Series Analysis, New Jersey: Princeton University Press.

Hoch, S.J. and Banerji, S. (1993). "When Do Private Labels Succeed?," Sloan Management Review, 34: 57-67.

Hoch, S.J., Montgomery, A., and Park, Y. (2004). "Long-Term Growth Trends in Private Label Market Shares." (Working paper).

Inman, J.J., and McAlister, L. (1993). "A Retailer Promotion Policy Model Considering Promotional Signal Sensitivity," Marketing Science, 12: 339-357.

Kadiyali, V. (1996). "Entry, Its Deterrence, and Its Accommodation: A Study of the US Photographic Film Industry," RAND Journal of Economics, 27: 452-478. 
Kumar V., and Leone, R.P. (1988). "Measuring the Effect of Retail Store Promotions on Brand and Store Substitution," Journal of Marketing Research, 25: 178-185.

McKinsey Quarterly, January (2011), “Have You Tested Your Strategy Lately?” Available [online] at: https://www.mckinseyquarterly.com/Have_You_Tested_Your_Strategy_Lately_2711

McLauglin, K. (2004). “Analyst Comment,” Marketing, (December) 8: 33.

Mulhern F.J. and Leone, R.P. (1991). "Implicit Price Bundling of Retail Products: A Multiproduct Approach to Maximizing Store Profitably," Journal of Marketing, 55: 63-76.

Narasimhan, C. and Wilcox, R.T. (1998). "Private Labels and the Channel Relationship: A CrossCategory Analysis,” Journal of Business, 71: 573-600.

Nevo, A. (2000). “A Practitioner's Guide to Estimation of Random Coefficients

Logit Model," Journal of Economics and Management Strategy, 9: 513-548.

PricewaterhouseCoopers, (2009)."Glimmers Amid the Gloom," Available [online] at: http://www.pwc.com/gx/en/retail-consumer/glimmers-gloom.

Private Label Buyer, (2007). "Charging Forward (Cover Story)," January. Available [online] at: http://www.privatelabelbuyer.com/content.php?s=PB/2007/01\&p=9

Private Label Magazine, (2004). "Store Brand Top Guns," April. Available [online] at: http://www.privatelabelmag.com/pdf/mar2004/print/3.cfm

-----, (2005). "Safeway Creates Destination Products," Available [online] at: http://www.privatelabelmag.com/pdf/july_2005/print/safeway.cfm

PLMA e-scanner, (2007). http://www.plma.com/pressupdate/pressupdate.asp

Progressive Grocer, (1997). "Rising Tide," 76: 17.

------, (2002). "The Slow Shakeout," 81: 17-23.

-----, (2002). “PG profile: Winn-Dixie,” 81: 18-24.

PROMO, (2005). "Private Plans," January 11.

Raju, J.S., Sethuraman, R.K., and Dhar, S.K. (1995). "The Introduction and Performance of Store Brands," Management Science, 41: 957-78.

Rosenblum, P. (2007). “Sourcing \& PLM Benchmark Report 2006-2007,” Available [online] at: http://www.Eqos.com

Schmalansee, R. (1983). "Advertising and Entry Deterrence: An Exploratory Model," Journal of Political Economy, 90: 636-653.

Scott-Morton, F. and Zettelmeyer, F. (2004). "The Strategic Positioning of Store Brands in RetailerManufacturer Negotiations," Review of Industrial Organization, 2: 161-194.

Sethuraman, R, Srinivasan, V., and Kim, D. (1999). "Asymmetric and Neighborhood Cross-Price Effects: Some Empirical Generalizations,” Marketing Science, 18: 23-41.

Shugan, S.M. (1989). "Branded Variants," Research in Marketing. Summer Educator's Conference, August.

Spence, M.A. (1977). “Entry, Capacity, Investment and Oligopolistic Pricing,” Bell Journal of Economics, 8: 534-44. 
Srinivasan, K. (1991). "Multiple Market Entry, Cost Signaling and Entry Deterrence," Management Science, 37: 1539-1555.

Store Brands Decision, (2010), "PLMA Unveils Roundtable Decisions." A summary is available [online] at: http://www.storebrandsdecisions.com/news/2010/08/31/plma-unveils-roundtablereport.

Supermarket News, (2000). "Fresh Profits in Store Brands," 17(April): 39-40.

The Hub Magazine, (2010), "Positively Safeway," Jan/Feb copy is available [online] at: http://www.hubmagazine.com/2009/12/positively-safeway-2/

Tirole, J. (1988). The Theory of Industrial Organization. Cambridge, MA: MIT Press.

Ward, M.B., Shimshack, J.P., Perloff, J.M., and Harris, M. (2002) "Effects of the Private Label Invasion in Food Industries," American Journal of Agricultural Economics, 84: 961-973.

Wolinsky, A. (1987). "Brand Names and Price Discrimination," Journal of Industrial Economics, 35: 255-268.

\section{Appendix}

\section{Analytical Model Solution}

With the first mover advantage, retailer $s$ acts as the Stackelberg leader and uses retailer $w$ 's best response function in its profit maximization. We need to find retailer $w$ 's best response function given retailer $s$ 's decision. We know from Eq (8) that $\Pi^{w}=m q_{n b}+q_{p l}^{w}\left(B^{\prime}-b^{\prime} q_{p l}^{w}-b_{1}^{\prime} q_{p l}^{s}-b_{2}^{\prime} q_{n b}-c_{p l}^{w}\right)-F^{w}$. In addition, each unit of private label cannibalizes the national brand sales, $q_{n b}$ equals to $0.5\left(1-c-m-q_{p l}^{s}-q_{p l}^{w}\right)$. By inserting, 0.5(1-c-m- $\left.q_{p l}^{s}-q_{p l}^{w}\right)$ for $q_{n b}$ and taking the second derivative, we have $\frac{d^{2} \Pi^{w}}{d q_{p l}^{w^{2}}}=-2\left(b^{\prime}-b_{2}^{\prime}\right)<0$.

We see that the second order condition holds. Then, we take the first derivative with respect to $q_{p l}^{w}$ and equate it to zero. We find $-m 0.5+\left(B^{\prime}-2 b^{\prime} q_{p l}^{w^{*}}-b_{1}^{\prime} q_{p l}^{s}-b_{2}^{\prime} 0.5\left(1-c-m-q_{p l}^{s}-2 q_{p l}^{w^{*}}\right)-c_{p l}^{w}\right)=0$.

By solving for $q_{p l, \text { we have }}^{w}$

$q_{p l}^{w^{*}}=\frac{B^{\prime}-0.5 m\left(1-b_{2}^{\prime}\right)-b_{2}^{\prime} 0.5(1-c)-c_{p l}^{w}-0.5\left(2 b_{1}^{\prime}-b_{2}^{\prime}\right) q_{p l}^{s}}{2 b^{\prime}-b_{2}^{\prime}}$.

Given the strong retailer's quantity of $q_{p l}^{s}$ units, the optimal best response for the weak retailer requires $q_{p l}^{w^{*}}=\frac{B-0.5 b_{1} q_{p l}^{s}}{b}$, where $B=B^{\prime}-0.5 m\left(1-b_{2}^{\prime}\right)-0.5 b_{2}^{\prime}(1-c)-c_{p l}^{w}, b_{1}=2 b_{1}^{\prime}-b_{2}^{\prime}$, and $b=2 b^{\prime}-b_{2}^{\prime}$. FromEq(7), we know that $\Pi^{s}=m q_{n b}+q_{p l}^{s}\left(A^{\prime}-a^{\prime} q_{p l}^{s}-a_{1}^{\prime} q_{p l}^{w^{*}}-a_{2}^{\prime} q_{n b}-c_{p l}^{s}\right)-F^{s}$, where $q_{p l}^{w^{*}}=\frac{B-0.5 b_{1} q_{p l}^{s}}{b}$. The second order condition requires a negative second 
derivative. We have $\frac{d^{2} \Pi^{s}}{d q_{p l}^{s^{2}}}=-\left(2 a^{\prime}-a_{2}^{\prime}\right)+\frac{b_{1}}{2 b}\left(2 a_{1}^{\prime}-a_{2}^{\prime}\right)$, which is negative since $2 a^{\prime}-a_{2}^{\prime}>2 a_{1}^{\prime}-a_{2}^{\prime}>\frac{b_{1}}{2 b}\left(2 a_{1}^{\prime}-a_{2}^{\prime}\right)$. We take the first derivative and equate it to zero. We find $-0.5 m\left(1-\frac{0.5 b_{1}}{b}\right)+A^{\prime}-2 a^{\prime} q_{p l}^{s^{*}}-a_{1}^{\prime} \frac{B-b_{1} q_{p l}^{s^{*}}}{b}-a_{2}^{\prime} 0.5\left(1-c-m-2 q_{p l}^{s^{*}}-\frac{B-b_{1} q_{p l}^{s^{*}}}{b}\right)-c_{p l}^{s}=0$ We obtain $\quad q_{p l}^{s^{*}}=\frac{A^{\prime}-0.5 m\left(\left(1-0.5 b_{1} / b\right)-a_{2}^{\prime}\right)-a_{2}^{\prime} 0.5(1-c)-c_{p l}^{s}-0.5\left(2 a_{1}^{\prime}-a_{2}^{\prime}\right) B / b}{\left(2 a^{\prime}-a_{2}^{\prime}\right)-0.5\left(2 a_{1}^{\prime}-a_{2}^{\prime}\right) b_{1} / b}$ We can write this as: $\quad q_{p l}^{s^{*}}=\frac{A-a_{1} B / 2 b}{a-a_{1} b_{1} / 2 b}, \quad$ where $A=A^{\prime}-0.5 m\left(\left(1-0.5 b_{1} / b\right)-a_{2}^{\prime}\right)-a_{2}^{\prime} 0.5(1-c)-c_{p l}^{s}, \quad a_{1}=2 a_{1}^{\prime}-a_{2}^{\prime} \quad, \quad a=2 a^{\prime}-a_{2}^{\prime}$. At the duopoly first best, by inserting $q_{p l}^{s^{*}}$ in $q_{p l}^{w^{*}}=\frac{B-0.5 b_{1} q_{p l}^{s^{*}}}{b}$, we have $q_{p l}^{w^{*}}=B / b-\frac{b_{1} A-a_{1} b_{1} B / 2 b}{2 a b-a_{1} b_{1}}$. Note that $a_{1}$ and $b_{1}$ give the price sensitivities since $a_{1}=2 a_{1}^{\prime}-a_{2}^{\prime}=\dot{a}_{1} /\left(1-\dot{a}_{1} \dot{b}_{1}\right)$ and $b_{1}=2 b_{1}^{\prime}-b_{2}^{\prime}=\dot{b}_{1} /\left(1-\dot{a}_{1} \dot{b}_{1}\right)$.

The positive private label sales as part of the duopoly first best require $q_{p l}^{s}<\frac{2 B}{b_{1}}$. Otherwise, retailer $w$ does not introduce a private label. Hence for $q_{p l}^{s^{*}}=\frac{A-a_{1} B / 2 b}{a-a_{1} b_{1} / 2 b}$ we need to have $\frac{A-a_{1} B / 2 b}{a-a_{1} b_{1} / 2 b}<\frac{2 B}{b_{1}}$. In order to see the maximum value for $q_{p l}^{s^{*}}$, take $\dot{a}_{1}$ and $\dot{a}_{2}$ close to zero. This condition results in $b_{1}=2 \dot{b}_{1}, a_{1}=0, a=2$. (In addition, we obtain the following parameters: $a^{\prime}$ equals one , $a_{1}^{\prime}$ and $a_{2}^{\prime}$ close to zero, $b^{\prime}$ equals $1+\dot{b}_{2}, b_{1}^{\prime}$ equals $\dot{b}_{1}+\dot{b}_{2}, b_{2}^{\prime}$ equals $2 \dot{b}_{2}, b=2, a=2$.) This provides the condition $A \dot{b}_{1}<B$ for $q_{p l}^{s^{*}}=\frac{A-a_{1} B / 2 b}{a-a_{1} b_{1} / 2 b}$. We need to have a positive national brand quantity, or $1-c-m-q_{p l}^{s}-q_{p l}^{w^{*}}>0$. This requires $\frac{b(1-c-m)-B}{b-0.5 b_{1}}>q_{p l}^{s}$. We need to have $\frac{2(1-c-m)-B}{2-\dot{b}_{1}}>q_{p l}^{s}$. In addition, the private label quantity should be positive, this requires $\frac{A-a_{1} B / 2 b}{a-a_{1} b_{1} / 2 b}>0, A>a_{1} B / 2 b$ and $a>a_{1} b_{1} / 2 b$. With strong private labels $\left(a_{1}\right.$ is low and close to zero), it holds. The private label prices should be positive. $B^{\prime}-b^{\prime} q_{p l}^{w^{*}}-b_{1}^{\prime} q_{p l}^{s}-b_{2}^{\prime} q_{n b}>0$, 
O r

$$
B^{\prime}-b^{\prime} \frac{B-0.5 b_{1} q_{p l}^{s}}{b}-b_{1}^{\prime} q_{p l}^{s}-b_{2}^{\prime} 0.5\left(1-c-m-q_{p l}^{s}-\frac{B-0.5 b_{1} q_{p l}^{s}}{b}\right)>0
$$

which equals $b B^{\prime}-b^{\prime}\left(B-0.5 b_{1} q_{p l}^{s}\right)-b b_{1}^{\prime} q_{p l}^{s}-b_{2}^{\prime} 0.5 b\left(1-c-m-q_{p l}^{s}\right)+b_{2}^{\prime} 0.5\left(B-0.5 b_{1} q_{p l}^{s}\right)>0$ or $\quad 2 B^{\prime}-\left(1+\dot{b}_{2}\right)\left(B-\dot{b}_{1} q_{p l}^{s}\right)-2\left(\dot{b}_{1}+\dot{b}_{2}\right) q_{p l}^{s}-2 \dot{b}_{2}\left(1-c-m-q_{p l}^{s}\right)+\dot{b}_{2}\left(B-\dot{b}_{1} q_{p l}^{s}\right)>0$

After simplifications, we have $2 B^{\prime}-B-\dot{b}_{1} q_{p l}^{s}-2 \dot{b}_{2}(1-c-m)>0$ or $\frac{B+m}{\dot{b}_{1}}>q_{p l}^{s}$. With $\frac{B+m}{\dot{b}_{1}}>\frac{2(1-c-m)-B}{2-\dot{b}_{1}}$, as a regularity condition, we need to have $\frac{2(1-c-m)-B}{2-\dot{b}_{1}}>q_{p i}^{s}$ Next, we show $q_{p l}^{s^{*}}>q_{p l}^{w^{*}}$. We know that $q_{p l}^{s}>q_{p l}^{w^{*}}=\frac{B-0.5 b_{1} q_{p l}^{s}}{b} \quad$ iff $q_{p l}^{s}>\frac{B}{b+0.5 b_{1}}$. We need to show that $q_{p l}^{s^{*}}=\frac{A-a_{1} B / 2 b}{a-a_{1} b_{1} / 2 b}>\frac{B}{b+0.5 b_{1}}$. This condition holds when $\left(A-a_{1} B / 2 b\right)\left(b+0.5 b_{1}\right)>B\left(a-a_{1} b_{1} / 2 b\right)$, or $\frac{A}{B}>\frac{2 a+a_{1}}{2 b+b_{1}}$. Note that $1>\frac{2 a+a_{1}}{2 b+b_{1}}$ and when $A>B$ it holds. With strong private label, this requires $\frac{A}{B}>\frac{4}{4+2 \dot{b_{1}}}$, or $\left(\left(4+2 \dot{b}_{1}\right) A^{\prime}-4 B^{\prime}\right)+2 m\left(\dot{b}_{1}-0.25 \dot{b}_{1}^{2}-2 \dot{b}_{2}\right)+4 \dot{b}_{2}(1-c)>0$, which holds.

We see that as $b_{1}$ increases, $q_{p l}^{w^{*}}$ decreases and $q_{p l}^{s^{*}}$ increases. In order to see the derivative of $q_{p l}^{s^{*}}$ with respect to $a_{1}$, consider $\frac{d}{a_{1}} q_{p l}^{s^{*}}=\frac{A b_{1}-B a}{2 b\left(a-a_{1} b_{1} / 2 b\right)^{2}}$. The maximum for the nominator is reached with the strongest private label when $b_{1}=2 \dot{b}_{1}$ and $a=2$. Then the nominator equals $2 A \dot{b}_{1}-2 B$. But $q_{p l}^{s^{*}}=\frac{A-a_{1} B / 2 b}{a-a_{1} b_{1} / 2 b}$ when $q_{p l}^{w^{*}}$ is positive. Since $A \dot{b}_{1}<B$ for observing $q_{p l}^{s^{*}}=\frac{A-a_{1} B / 2 b}{a-a_{1} b_{1} / 2 b}, \frac{d}{a_{1}} q_{p l}^{s^{*}}<0$.

\section{Proof of Proposition 1}

Introducing a private label enables retailer $s$ to be more competitive and to decrease the national brand prices when competing against $w$ retailer. When the $w$ private label quality is not sufficiently high and $\dot{b}_{1}>B / A$, retailer $w$ does not introduce private label as part of its duopoly first best. In general, we know that if $q_{p l}^{s}>\frac{2 B}{b_{1}}$, weak retailer $w$ does not introduce private label. For this to be a valid range for $q_{p l}^{s}$, we need to have $\frac{b(1-c-m)-B}{b-0.5 b_{1}}>q_{p l}^{s}>\frac{2 B}{b_{1}}$, or, $\frac{b(1-c-m)-B}{b-0.5 b_{1}}>\frac{2 B}{b_{1}}$. This condition requires that 
$\dot{b}_{1}(1-c-m)>B$. Hence, it is possible that a strong private label commitment creates an incentive not to introduce $w$ private label.

With no $w$ private label, retailer $w$ obtains a (national brand) profit of $\Pi^{w^{*}}=m q_{n b}$. Retailer $w$ stays in the market providing $\Pi^{w^{*}}=m q_{n b} \geq T$, or as long as $m \geq T / q_{n b}$. Note that $\Pi^{s}=m q_{n b}+\Pi_{P L}^{s}-F^{s}$ where $\Pi_{P L}^{s}$ represents the private label's contribution to retailer $s^{\prime}$ 's profit. $\Pi^{s}=m q_{n b}+\Pi_{P L}^{s}-F^{s} \geq T$ requires that $m \geq\left(T+F^{s}-\Pi_{P L}^{s}\right) / q_{n b}$. But, $\Pi_{P L}^{s}>F^{s}$ and $T / q_{n b}>\left(T+F^{s}-\Pi_{P L}^{s}\right) / q_{n b}$. Hence with lower national brand margins, retailer $w$ leaves the market since retailer $w$ cannot survive in the market. A similar logic also applies to the case where both retailers have private labels. In this case, the conditions require $m \geq\left(T+F^{w}-\Pi_{P L}^{w^{*}}\right) / q_{n b}$ and $m \geq\left(T+F^{s}-\Pi_{P L}^{s}\right) / q_{n b}$ for the $w$ and $s$ retailers to stay in the market, respectively. With $\Pi_{P L}^{s}-F^{s} \geq \Pi_{P L}^{w^{*}}-F^{w}$, while $T>\Pi_{P L}^{w^{*}}-F^{w}$ the previous argument holds. With very low threshold profits such that $\Pi_{P L}^{w^{*}}-F^{w}>T$, both retailers can survive in the market. At the other extreme, with very low national brand margins and profitable private labels, retailer $w$ can also obtain a higher than threshold level profit with private labels. Then, retailer $w$ obtains a profit of $\Pi^{w^{*}}\left(q_{p l}^{s}\right)=q_{p l}^{w^{*}}\left(B^{\prime}-b^{\prime} q_{p l}^{w^{*}}-b_{1}^{\prime} q_{p l}^{s}-b_{2}^{\prime}(1-c)-c_{p l}^{w}\right)-F^{w}$, where $q_{p l}^{w^{*}}=\frac{B-0.5 b_{1} q_{p l}^{s}}{b}$, where $B=B^{\prime}-0.5 b_{2}^{\prime}(1-c)-c_{p l}^{w}, b_{1}=2 b_{1}^{\prime}-b_{2}^{\prime}$, and $b=2 b^{\prime}-b_{2}^{\prime}$. Duopoly first best calls for $q_{p l}^{s^{*}}=\frac{A-a_{1} B / 2 b}{a-a_{1} b_{1} / 2 b}$, where $A=A^{\prime}-a_{2}^{\prime} 0.5(1-c)-c_{p l}^{s}, a_{1}=2 a_{1}^{\prime}-a_{2}^{\prime}$, $a=2 a^{\prime}-a_{2}^{\prime}$. In this case, when both firms follow their duopoly first best $\Pi^{s^{*}}>\Pi^{w^{*}}>T$, where $\Pi^{s^{*}}$ and $\Pi^{w^{*}}$ represents the duopoly first best profits for $s$ and $w$ retailers. However, retailer $s$ can still do better. When retailer $s$ increases its private label commitment and distorts its first best, retailer $w$ private label sales and profit decline. But, $s$ retailer has the incentive to increase its commitment to $q_{p l}^{s, e}$ providing that $\Pi^{s, \text { monopoly }}\left(q_{p l}^{s, e}\right)>\Pi^{s^{*}}$ while $\Pi^{w^{*}}\left(q_{p l}^{s, e}\right) \leq T$, where $\Pi^{s, m o n o p o l y}\left(q_{p l}^{s, e}\right)$ represents the post exit profit for retailer $s$ and $\Pi^{w^{*}}\left(q_{p l}^{s, e}\right)$ represents the duopoly best profit for retailer $w$ as a function of retailer s commitment $q_{p l}^{s, e} \cdot{ }^{[9]}$ Hence, the optimal exit strategy calls for setting $q_{p l}^{s, e^{*}}$ such that $\Pi^{w^{*}}\left(q_{p l}^{s, e}\right)$ is $\varepsilon$ smaller than $T$ while $\Pi^{\text {s,monopoly }}\left(q_{p l}^{s, e^{*}}\right)>\Pi^{s^{*}}$, where $\varepsilon$ is a small positive number.

\section{Proof of Proposition 2}

The strong retailer needs to ensure that the weak retailers' profit is less than the threshold (i.e. $m q_{n b} \leq T$ ). This requires $q_{n b}=T / m$ at the maximum. However, as $m$ increases, $q_{n b}$ needs to decrease for the incentive to exit to be maintained. By selling an even higher quantity of private labels, retailer $s$ needs to further cannibalize from the national brand profit. Consequently, this requires an even higher level of private label sales.

\footnotetext{
${ }^{[9]}$ Post exit, market reverts to a monopoly. The resulting limited competition for retailer $s$ provides an incentive to distort the duopoly first best strategy and commit to higher levels of private label sales. With no retailer $\mathrm{w}$ in the market, we have retailer $\mathrm{s}$ facing $q_{p l}^{s}=A^{\prime \prime}-p_{p l}^{s}+a_{2}^{\prime \prime} p_{n b}$. Post exit, retailer $s$ profit function equals $m\left(1-c-m-q_{p l}^{s, e}\right)+q_{p l}^{s, e}\left(A^{\prime \prime}-q_{p l}^{s, e}+a_{2}^{\prime \prime} p_{n b}-c_{p l}^{s}\right)-F^{s}$ where $q_{p l}^{s, e}$ is the committed amount by retailers.
} 